
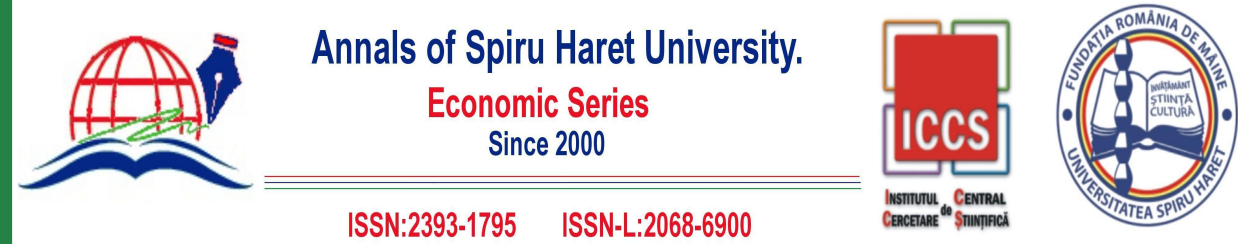

Issue 3/2019

\title{
RETHINKING PERSUASION IN RELIGIOUS SYMBOLIC COMMUNICATION: A MARKETING POINT OF VIEW
}

\author{
Ciprian Adrian GHINEA ${ }^{1}$ \\ ${ }^{1}$ Transilvania University of Brașov, Inter-disciplinary Doctoral School, \\ B-dul Eroilor No. 29, Brașov, România, Tel.: +40-(268) 41.30.00, \\ Fax:+40-(268) 41.05.25, Email: adrian.ghinea@unitbv.ro
}

How to cite: GHINEA, C. A. (2019). "Rethinking Persuasion in Religious Symbolic Communication: A Marketing Point of View." Annals of Spiru Haret University. Economic Series, 19(3), 101-110, doi: https://doi.org/10.26458/1936

\begin{abstract}
The marketing dynamics of the study and praxis of persuasion present different interweavings with the time frame chosen. Even so, we consider that the only one offering a stable reference background is religious communication, because even if interpretations may differ, the basic principles of association towards individual apprehension and comprehension remain the same. It is the author intention to try to map out possible connections between persuasion, as a symbolic process, and religious symbolic communication, by assuming that, in a Biblical sense, communication is intrinsic to the act of being of all humanity.
\end{abstract}

Keywords: symbol; significance; language; persuasion; symbolic processing.

JEL Classification: M31, Z13

\section{Introduction}

The authentic religious communication has as a main characteristic the fact that tends to be ineffable. From this respect, the religious discourse needs a proper "translation" from apart specialists into a more effable form. [Turner, 2008]

Religious cues have an important role within marketing communications across different cultural backgrounds. Drawing on symbolic interactionism theory, researchers 

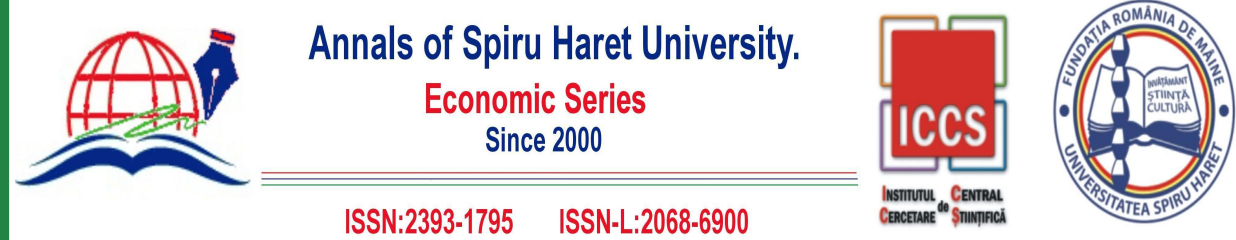

\section{Issue 3/2019}

have found symbols that possess symbolic value with religious people influencing their buying behaviour and perception upon products image. [Bakar, Lee \& Rungie, 2013]

Also, other research suggest that the Christian cross can be only a peripheral cue but as well as a central part of the persuasive message used in health advertisements. [Lumpkins, 2010] Thus the religious symbolic communication has a strong connection with the persuasion process that can affect attitudes, beliefs and values of individuals. The academic literature has developed over time numerous major concepts such as Elaboration Likelihood Model, the Extended Parallel Process Model, and Cognitive Dissonance Theory that can be applied for a diversity of fields in order to explain and analyze the process of persuasion and the mechanism that entails transformation of attitudes and beliefs. [Perloff, 2010]

The present article will explore the complex meaning of persuasion process seen as a symbolic process and the connections that can be made with symbolic religious communication. As we have stated above, marketing communication discourse will use different persuasion techniques in order to achieve marketing specific goals for organizations.

From a marketing perspective, the symbolism of different religious images is integrated into the marketing communication appealing to a deep cultural and spiritual layer of individuals' personality. [Gârdan \& Geangu, 2013]

Thus, there is the need for an inter-disciplinary approach in order to explain the subtle link that can be established between inner values and beliefs on one hand and religious symbolism that can be used for persuasion on the other hand.

\section{Literature Review Concerning Persuasion and Symbolic Religious Communication}

The study and praxis of persuasion are not new, since they can be traced even in the Old Testament, when Jeremiah tried to persuade his people to repent in front of the Lord. [Perloff, 2010] Furthermore, persuasion may be depicted when John the Baptist preaches on the arrival of Jesus Christ: "John testified concerning him. He cried out, saying, "This is the one I spoke about when I said, "He who comes after me has surpassed me because he was before me'." [Ioan, 1:15], thus building on the credibility of Jesus, playing the part of the advance-man [Whalen, 1996], namely the one sent before an actual event in order to build expectations and create a framing of expectations regarding the main character/figure in the event. 


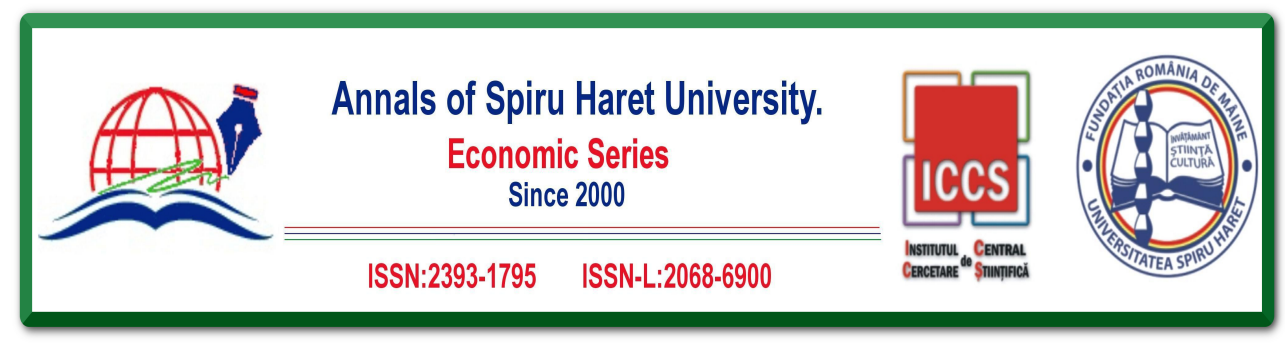

Issue 3/2019

The dynamics of the study of persuasion manifests different rhythms, based on the chosen time frame - each presents a set of traits, a specific tempo and a specific socio-emotional fingerprint. This is the reason why persuasion, or persuasive communication unfolds in a different manner, it being grafted on the set of traits of the period and domain we reference.

Academia has provided several definitions for persuasion. From the communication studies perspective, we have selected the following:

- a communication process in which the sender of the message seeks to elicit a distinct response from the receiver of the message [Andersen, 1971];

- a deliberate endeavour of one individual to alter the attitudes, beliefs and behaviours of another person through the sending of a certain type of message [Bettinghaus \& Cody, 1994];

- a symbolic activity with the purpose of achieving the voluntary acceptance of different behaviour patterns and/or cognitive states through an exchange of messages [Smith, 1982];

- wilful effort to influence the mental state of an individual through communication in a context in which the person to influence benefits of a certain degree of freedom [O'Keefe, 2016].

All these definitions present their strengths, but should we chose to unite all their main components into a definition which is aligned with the purpose of our research, we would embrace Perloff definition, namely that persuasion represents a symbolic process through which those sending a message attempt to convince the receivers of that message to change their own attitudes and behaviours related to a specific topic, by engaging in this process in a free will environment [Perloff, 2010].

This definition encompasses five components: persuasion as a symbolic process, persuasion as an attempt to influence, persuasion includes a self-persuasion component, persuasion contains the transmission of a message and persuasion befits the existence of a free will component. For this paper we will focus on the first component, namely persuasion as a symbolic process and the way this definition paves the way to revealing connections to the symbolic religious communication.

In a Biblical sense, communication is achieved within a trinity framing, therefore at the essential roots of the being and of the real. The second person of the Holy Trinity is named Logos, or Word, because it refers to the inward communication of Self that the Holy Father performs in its entirety towards his Son, in the name of the Love which is represented by the Holy Spirit. From St. Augustin hither, the 


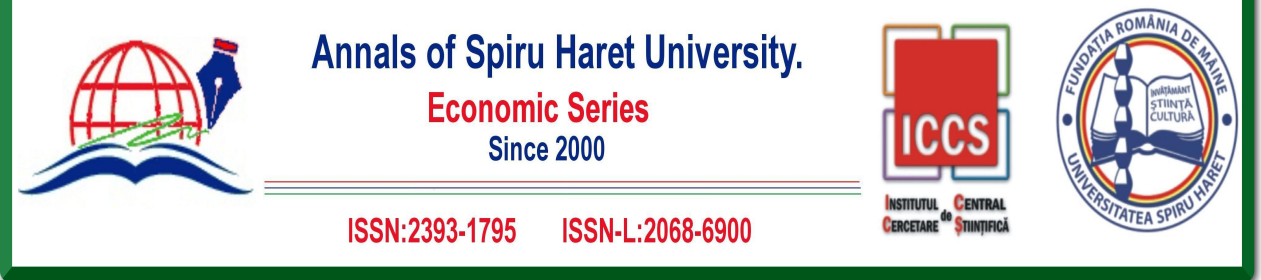

\section{Issue 3/2019}

relationship Father-Spirit has been considered analogical to the "Pater-Filius" relationship, considered foundational to the procession of the Spirit ex patre filioque". Moving inward, this relationship is considered by Augustine as unity preserving, according to the divine essence, quoting also from John 10:30 in order to defend the unity between the Father and the Son: "It is in this sense that [John] says I and the Father are one; 'are one' means 'What he is, that I am too by way of being, not by way of relationship'." [Hill \& Rotelle, 1990]. Again it is noticeable that the PaterFilius rational is elemental for the pneumatological ${ }^{2}$ doctrine: "just as the Father, then, begot and the Son was begotten, so the Father sent and the Son was sent. But just as the begetter and the begotten are one, so are the sender and the sent, because the Father and the Son are one; so too the Holy Spirit is one with them, because these three are one." [Hill \& Rotelle, 1990].

Exploring the depth of this definition and its pertinence in the current context of communication sciences is an ongoing process, we might even consider it never ending. Therefore, communication is not to be considered an accidental activity or a prerogative, but intrinsic to the act of being of all humanity. Man is created after the image of the Pater, who is communication. In any authentic communication, we consider that a portrayal of the Holy Trinity may be depicted, since there is One who communicates, there is One to whom the communication is addressed and the communication itself, such as the Holy Trinity is a continual becoming from the Pater who loves, the Filius who is bestowed upon with love and the Holy Spirit which is love.

In marketing, the truest of communication is never one to be uniquely defined but is always an act of giving and of receiving, and act of talking and of hearing. It is a similar outlook to communication derived from within the conceptualization of the

\footnotetext{
${ }^{1}$ This expression refers to the inquiry Does the Holy Spirit proceed from the Father only, as Eastern Christendom contends, or from both the Father and the Son (ex Patre Filioque), as the Latin Church teaches? More information: https://summaphilosophiae. wordpress.com/2006/07/25/ex-patre-filioque/ Accessed on 20.07.2019

2 The term pneumatology comes from two Greek words, namely, pneuma meaning "wind," "breath," or "spirit" (used of the Holy Spirit) and logos meaning "word," "matter," or "thing." As it is used in Christian systematic theology, "pneumatology" refers to the study of the biblical doctrine of the Holy Spirit. Generally this includes such topics as the personality of the Spirit, the deity of the Spirit, and the work of the Spirit throughout Scripture.
} 


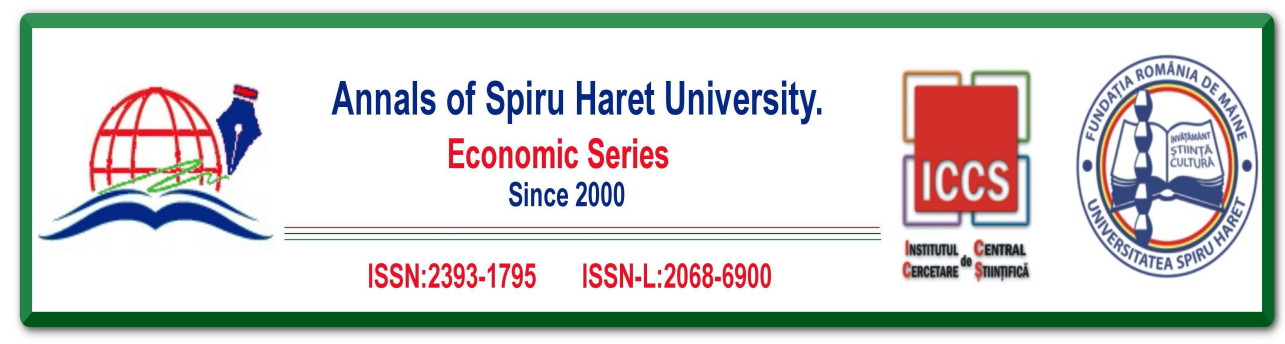

Issue 3/2019

Holy Trinity: the Filius is a becoming of the word of love of the Pater and a coming into being of the answer of love offered to the Pater. Thus, paraphrasing John: "In the beginning was the Word, and the Word was with God, and the Word was God." [John, 1:1], or from our point of view: communication was the beginning.

This outlook on communication is possible only where God is conceived not as absolute power, or absolute cosmic law, like in antic or modern religious systems, but is understood as absolute love. Power and law can be wielded by a singularity, but it is not the same with love. Love needs an I who loves and a You who is loved. Therefore, this understanding of God spreads throughout those who believe because it is communication unfolding from and towards love. What arises from the inwardness of God conveys firstly in the history of redemption. The Biblical revelation is both communication and dialogue. God speaks to man, but man speaks unto God in/through the Bible. From an ecclesiastic outlook, the importance of communication resides in this originating point: when it is risen from seeking truth and love, communication is the only means of building bridges between the islands which are men ${ }^{3}$ until the shore which is God.

Persuasion, as a Symbolic Process and Symbolic Religious Communication

Persuasion implies a setting aside of time, it consists in executing certain steps in a specific order and it actively involves the receiver of the message. Furthermore, it is a process which implies using symbols, no matter if used in advertising or marketing communications. It is our intention to draw out the approach of persuasion as a symbolic process, an approach with a rich background in marketing communications [O'Shaugnessy \& O'Shaughnessy, 2003]; [Miles, 2013]; [Lannon, 1994]; [Epure, Eisenstat \& Dinu, 2014] and to pinpoint connection markers to religious communication, by actively using the connotation of religious symbols as decoding mechanisms. The symbol is defined as any form of language used by a singular entity to portray a concept or an idea communicating, at the same time, psychological and cultural complex meanings.

Symbols act as tools for persuaders and are harnessed to activate change in attitudes and balancing, or moulding points of view and opinions. Therefore,

\footnotetext{
3 'No man is an island' is a quotation from the English metaphysical poet John Donne (1572-1631) and it appears in Devotions Upon Emergent Occasions and Severall Steps in my Sicknes - Meditation XVII, 1624.
} 


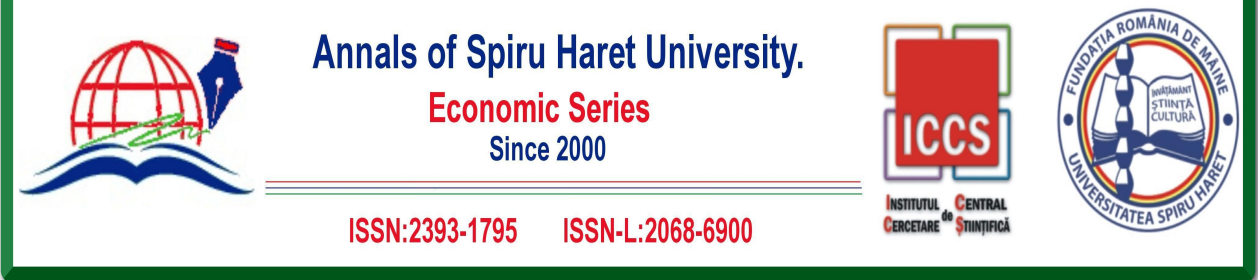

\section{Issue 3/2019}

persuasion does not activate at a literal level, since language itself undergoes multiple interpretations, and these arisen interpretations, or the meanings differ according to the imagination of the audience and to the different acceptations conveyed towards similar messages. For example, Jerusalem represents a holy place for the Jews inhabitants in the Middle East, since it is imprinted in their subconscious as the birthplace of the Jewish people spirit. For the Christians, it is a holy city, where Jesus preached and healed and organized the Last Supper. For the Muslims, Jerusalem is a holy place, where the Prophet Mohamed rose to Heaven.

The key-aspect of the persuasive intervention is represented by the process of activating the imagination and by projecting various significances of the same symbol, both multiple and fluid, towards the active and receiving audience [Perloff, 2010]. When these processes occur, the symbol becomes a mediation vehicle for a comprehensible presence and representation of the sacred under a variety of conventional and standardized forms [Moritz \& Goldammer, 2018].

The symbol presents an architecture of complementarity: the object, be it a painting, a word or a gesture, requires an association with an idea from the conscious realm for the embedded meaning in the object to manifest in its entirety. From this outlook, any symbol presents a double functionality: esoteric and exoteric, however any of these two functions requires an active cooperation between the members of group who trigger the production of meaning.

Religious symbols are used to diffuse concepts which imply the relationship between human and sacred or holy, such is the case of the Holy Cross. Lead symbol of Christian religion, the cross represents both the Crucifixion of Jesus Christ, as well as His death and resurrection as Son of God, therefore underpinning the Christian faith in God. On the other hand, in a ceremonial context, the cross may also represent an act of faith, a blessing or a prayer.

Should we strive to decode the persuasiveness layer of this symbol, we need to consider that Christian tradition has condensed in this symbol so many connotations [Becker, 2000], that each carries within its own projection of meaning. When used as a symbol for Crucifixion, it illustrates the passions of Christ, therefore prompting a representation of Christ through the Eucharist, which may be defined as a sacrament of love and as a source for "salvific grace and virtue" [Viladesau, 2006]. The persuasiveness strengths builds upon these meanings when used in sermons or other teachings, because it appeals to conventional ideas such as sacrifice for the benefits of others, doing good as a virtue or having mercy, and it is this projection that is done 106 


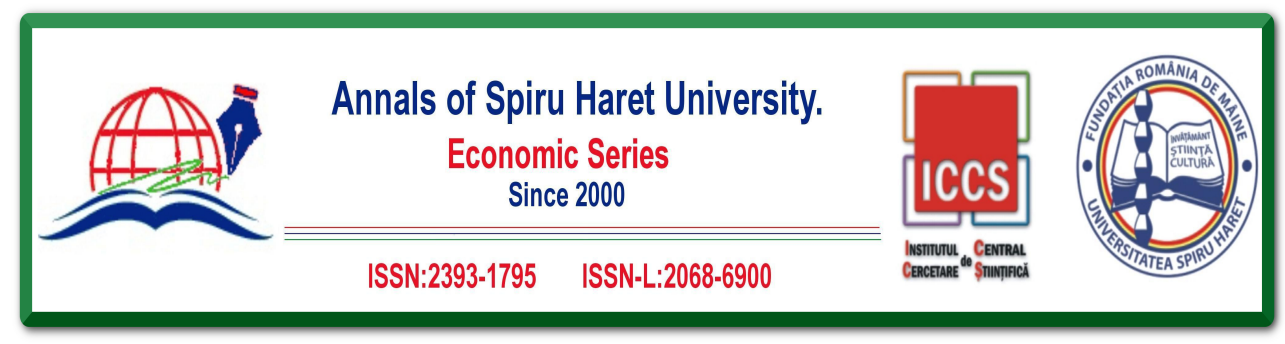

Issue 3/2019

not by the sender of the message, but by the audience who is willing to let the symbol produce the change.

When used as a gesture by a priest when preaching or delivering a sermon, the cross marks a "repetitive and rhythmic patterning [...] to lock in specific words, words carrying a powerful emotional or associational charge" [Allott, 2012]. There is the case for each ending of a prayer, which is always ended with the gesture of the cross, or during a sermon when blessings are bestowed by the preacher onto the participants at certain specific moments. Either considering the meaning architecture of a prayer or that of a sermon, the symbolic gesture of the cross implies two persuasive layers: a first one which refers to the voluntary imprinting of an emotion, usually derived from the Holy grace, and a second one referring to the thoughts verbalization, coming forth when each individual representation of the symbol becomes triggered in each individual stream of consciousness. Should we consider an alignment between the two as ideal, then this could constitute a locking of a persuasive stream within the audience.

Another function of the symbol is to represent a reality or a truth and to portray it by a gradual or synchronic act of revealing. The relationship between a symbol and the reality is built both in a dual and instant manner: both intimate and direct and distant and indirect, and that is due to the identification between the symbol with the reality that it represents. It may be either denotative or truly representative of the meaning encoded from that reality. For example, in the doctrine of the Eucharistic presence of Jesus Christ in the Eastern Orthodoxy or Roman Catholicism teachings there are extensive levels of symbolic significance, both as variety and as extensiveness. Let's consider the transubstantiation theory, which refers to the change by which the essence of the bread and wine becomes the body and blood of Jesus Christ, therefore allowing for a significance act to take place. There are three acts of revealing to be decoded in this instance: the gradual act of revealing the transformative process of the transubstantiation, the gradual act of revealing the opening up to listening process of the participants to the sermon [Pleizier, 2010] and the synchronic act of faith actualization, when the listener becomes part of an sequence with an amanetic character derived from the presence or re-presentation of the founding event [Faber, 2019] of the transubstantion, namely the Last Supper. All these acts carry within them a persuasiveness foundation, since all three events imply an interaction between God and the world changed by His presence, as He exercises influence on all events, but never is the sole cause of any of them [Cobb, 2008]. All 


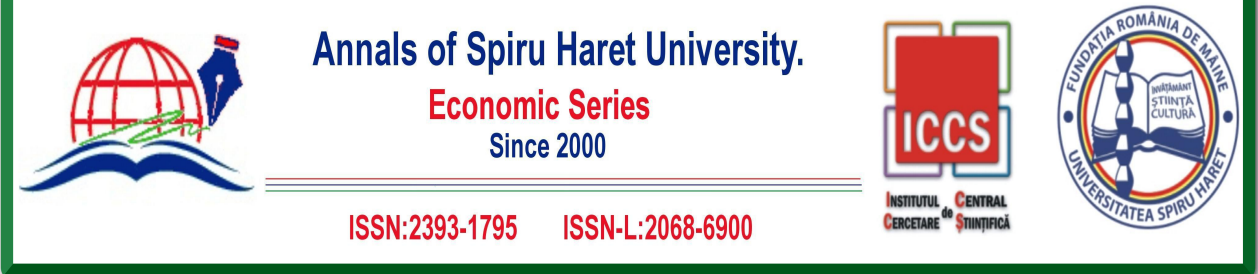

\section{Issue 3/2019}

events exercise their own creativity based on various triggers (either from listener imagination or preacher words), but also based on various degrees of freedom acted upon by divine infusions [Faber, 2019].

\section{Conclusions}

"God does never act by coercion, but always by persuasion" [Whitehead, 1942] and it is from this conclusion formulated by others more equipped to argue than the author, should we pursue to draw ours. As described in our article, the symbolic act of listening during a sermon can be defined as a persuasive intervention, since it brings about a three-fold act of revelation only possible through an active engagement of the listener. Furthermore, the religious symbol (i.e. the cross) can mediate a representation of the sacred, both as apprehension, namely as an emotional imprinting of the representation, and as comprehension, that is as a rational and conventional verbalization of what that symbol entails. Therefore, by using connotations of religious symbols as decoding mechanisms we were able to depict manifestation of persuasive layers in conventional forms of re-presentation of the sacred.

The deep meaning of these perceptions is integrated into the cultural dimension of consumers' behaviour and can be used as a background for a marketing communication process [Gârdan, Epuran \& Gârdan, 2016].

Future lines of research should explore through qualitative type marketing research how the marketing communication can use the process of persuasion considered as an symbolic process based on religious symbols in order to achieve marketing specific goals - related to consumers behaviour or social marketing programs for example.

In a dynamic business world, cultural, religious and anthropologic elements are combined altogether in order to achieve a convincing message for consumers, their inner experiential universe being explored very carefully during the process.

\section{References}

[1] Allott, R. The Great Mosaic Eye: Embodied Language Evolution and Society. Xlibris Corporation, 2012.

[2] Andersen, K. E. Persuasion: Theory and Practice. Boston: Allyn and Bacon, 1971.

[3] Bakar, A., Lee, R., \& Rungie, C. (2013). "The effects of religious symbols in product packaging on Muslim consumer responses." Australasian Marketing Journal, 21(3), 198-204. 


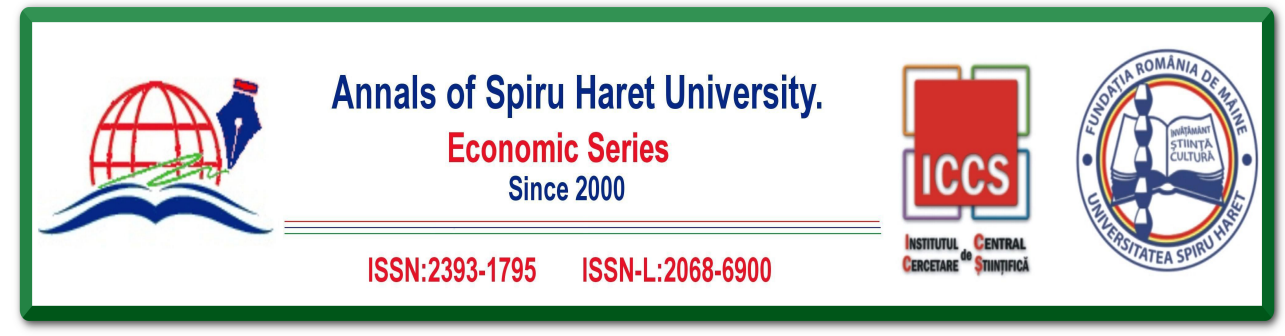

Issue 3/2019

[4] Becker, U. The Continuum Encyclopaedia of Symbols. A\&C Black, 2000.

[5] Bettinghaus, E. P., \& Cody, M. J. Persuasive communication (5th ed). Retrieved from https://trove.nla.gov.au/version/44810144, 1994.

[6] Cobb, J. B. Back To Darwin: A Richer Account of Evolution. Wm. B. Eerdmans Publishing, 2008.

[7] Epure, M., Eisenstat, E., \& Dinu, C. (2014). "Semiotics and persuasion in marketing communication." Linguistic and Philosophical Investigations, 13, 592.

[8] Faber, R. (2019). The Ocean of God: On the Transreligious Future of Religions. Anthem Press.

[9] Gârdan, D.A., Epuran, G., Gârdan, I.P. (2016). "Creating value within consumption culture, Studies and scientific researches." Economics Edition, 24, 45-58.

[10] Gârdan, D., \& Geangu, P. I. (2013). "Peculiarities of marketing communications in cultural marketing." Annals of Spiru Haret University. Economic Series, 13(3), 78-84.

[11] Hill, E., \& Rotelle, J. E. The Works of Saint Augustine: A Translation for the 21st Century. Brooklyn, N.Y: New City Press, 1990.

[12] John. (n.d.). Sfânta Evanghelie după Ioan: Capitolul 1. Retrieved July 20, 2019, from https://www.bibliaortodoxa.ro/noul-testament/35/Ioan

[13] Lannon, J. (1994). "Mosaics of Meaning: Anthropology and Marketing." Journal of Brand Management, 2(3), 155-168.

[14] Lumpkins, C. Y. (2010). "Sacred symbols as a peripheral cue in health advertisements: An assessment of using religion to appeal to African American women about breast cancer screening." Journal of Media and Religion, 9(4), 181-201.

[15] Miles, C. (2013). "Persuasion, marketing communication, and the metaphor of magic." European Journal of Marketing, 47(11/12), 2002-2019.

[16] Moritz, K., \& Goldammer, A. (2018). "Religious symbolism and iconography." In Encyclopaedia Britannica. Retrieved from https://www.britannica.com/topic/religioussymbolism

[17] O'Keefe, D. J. (2016). "Persuasion and social influence." The International Encyclopaedia of Communication Theory and Philosophy, 1-19.

[18] O'Shaugnessy, J., \& O'Shaughnessy, N. Persuasion in Advertising. Routledge, 2003.

[19] Perloff, R. M. The Dynamics of Persuasion: Communication and Attitudes in the Twenty-First Century, $4^{\text {th }}$ edition. Routledge, 2010.

[20] Pleizier, T. Religious Involvement in Hearing Sermons: A Grounded Theory Study in Empirical Theology and Homiletics. Eburon Uitgeverij B.V., 2010.

[21] Smith, M. J. Persuasion and Human Action: A Review and Critique of Social Influence Theories. Wadsworth Publishing Company, 1982.

[22] Turner, B. S. (2008). "Religious speech: The ineffable nature of religious communication in the information age." Theory, Culture \& Society, 25(7-8), 219-235. 


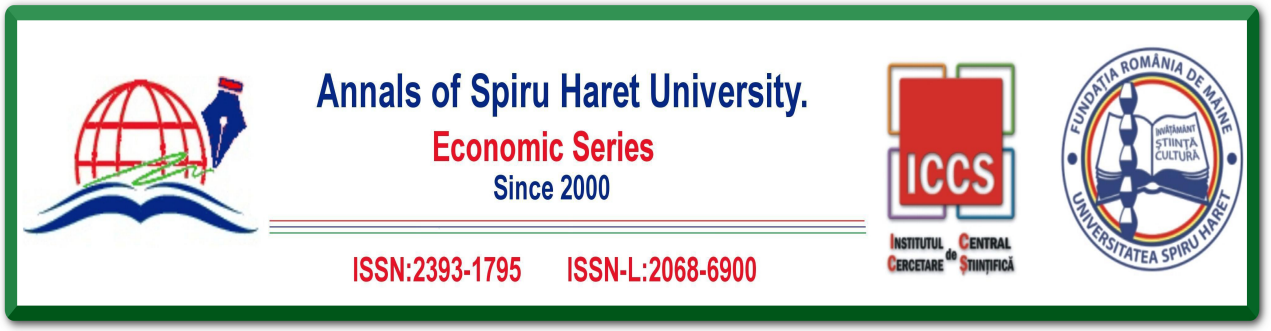

\section{Issue 3/2019}

[23] Viladesau, R. The Beauty of the Cross: The Passion of Christ in Theology and the Arts from the Catacombs to the Eve of the Renaissance. Oxford University Press, USA, 2006.

[24] Whalen, D. J. I See What You Mean: Persuasive Business Communication. Sage, 1996.

[25] Whitehead, A. N. Adventures of Ideas. CUP Archive, 1942. 